\title{
The Role of Metal Binding in the Amyotrophic Lateral Sclerosis-Related Aggregation of Copper-Zinc Superoxide Dismutase
}

\author{
Ivana Sirangelo (1) and Clara Iannuzzi * \\ Department of Biochemistry, Biophysics and General Pathology, Università degli Studi della Campania \\ “Luigi Vanvitelli”, 80138 Naples, Italy; ivana.sirangelo@unicampania.it \\ * Correspondence: clara.iannuzzi@unicampania.it; Tel.: +39-081-566-5810
}

Received: 19 July 2017; Accepted: 27 August 2017; Published: 29 August 2017

\begin{abstract}
Protein misfolding and conformational changes are common hallmarks in many neurodegenerative diseases involving formation and deposition of toxic protein aggregates. Although many players are involved in the in vivo protein aggregation, physiological factors such as labile metal ions within the cellular environment are likely to play a key role. In this review, we elucidate the role of metal binding in the aggregation process of copper-zinc superoxide dismutase (SOD1) associated to amyotrophic lateral sclerosis (ALS). SOD1 is an extremely stable $\mathrm{Cu}-\mathrm{Zn}$ metalloprotein in which metal binding is crucial for folding, enzymatic activity and maintenance of the native conformation. Indeed, demetalation in SOD1 is known to induce misfolding and aggregation in physiological conditions in vitro suggesting that metal binding could play a key role in the pathological aggregation of SOD1. In addition, this study includes recent advances on the role of aberrant metal coordination in promoting SOD1 aggregation, highlighting the influence of metal ion homeostasis in pathologic aggregation processes.
\end{abstract}

Keywords: metals; protein misfolding; SOD1; neurodegeneration; amyloid aggregation

\section{Introduction}

Protein misfolding, aggregation, and formation of insoluble amyloid deposits are common pathological hallmarks in many neurological disorders such as Huntington's, Alzheimer's, and Parkinson's diseases and amyotrophic lateral sclerosis (ALS) [1]. In these conformational diseases, misfolding and aggregation of proteins seem to be directly related to neurotoxicity [2,3]. In amyloid diseases, a normally soluble protein forms insoluble fibrillary structures that share common structural features despite the considerable diversity in the primary sequence of the component proteins. Indeed, amyloid fibrils are typically composed of unbranched fibrils rich in $\beta$-sheet structures in which the ordered regions adopt a cross- $\beta$ structure $[4,5]$. Although the aggregation process of proteins has been widely studied in vitro and many physiological factors have been identified, the molecular determinants that promote or modulate the abnormal protein-protein interactions, leading to protein aggregation, remain elusive. Among them, metal ions seem to play a key role in amyloid aggregation as they were shown to be directly involved in many neurodegenerative disorders like Alzheimer's, Parkinson's and prion diseases. In particular, metal binding has been shown to strongly affect both protein oligomerization and neurotoxicity in $\beta$-amyloid peptide, $\alpha$-synuclein, prion protein, human islet amyloid polypeptide and superoxide dismutase 1 [6-11]. In addition, metal ion homeostasis is a hallmark in neurodegenerative conditions [12]. Eukaryotic copper-zinc superoxide dismutase 1 (SOD1) is a 32-kDa homodimeric metalloenzyme and each homodimer contains an active site that binds a catalytic copper ion and a structural zinc ion (Figure 1). The mature, correctly folded and enzymatically active form is obtained in vivo through several post-translational modifications: binding 
of zinc and copper ions, disulfide bond formation, and dimerization [13-15]. SOD1 is implicated in the formation of proteinaceous toxic aggregates in the affected motor neurons of familial and sporadic forms of ALS [16-23]. Indeed, SOD1 is an extremely stable protein when fully assembled, but it is rather unstable and prone to aggregation in its metal-free form. Many studies have shown that wild-type human SOD1, when lacking both its metal ions, forms large and stable amyloid-like protein aggregates under physiological conditions of $\mathrm{pH}$ and temperature thus suggesting that metal binding could play a key role in the in vivo aggregation process of SOD1 [15,24-29]. Moreover, it has been reported that also some SOD1 mutants, many of them related to familial ALS, form amyloid aggregates both in vitro and in vivo and that demetalation is the key factor for aggregation [15,25,29-36].

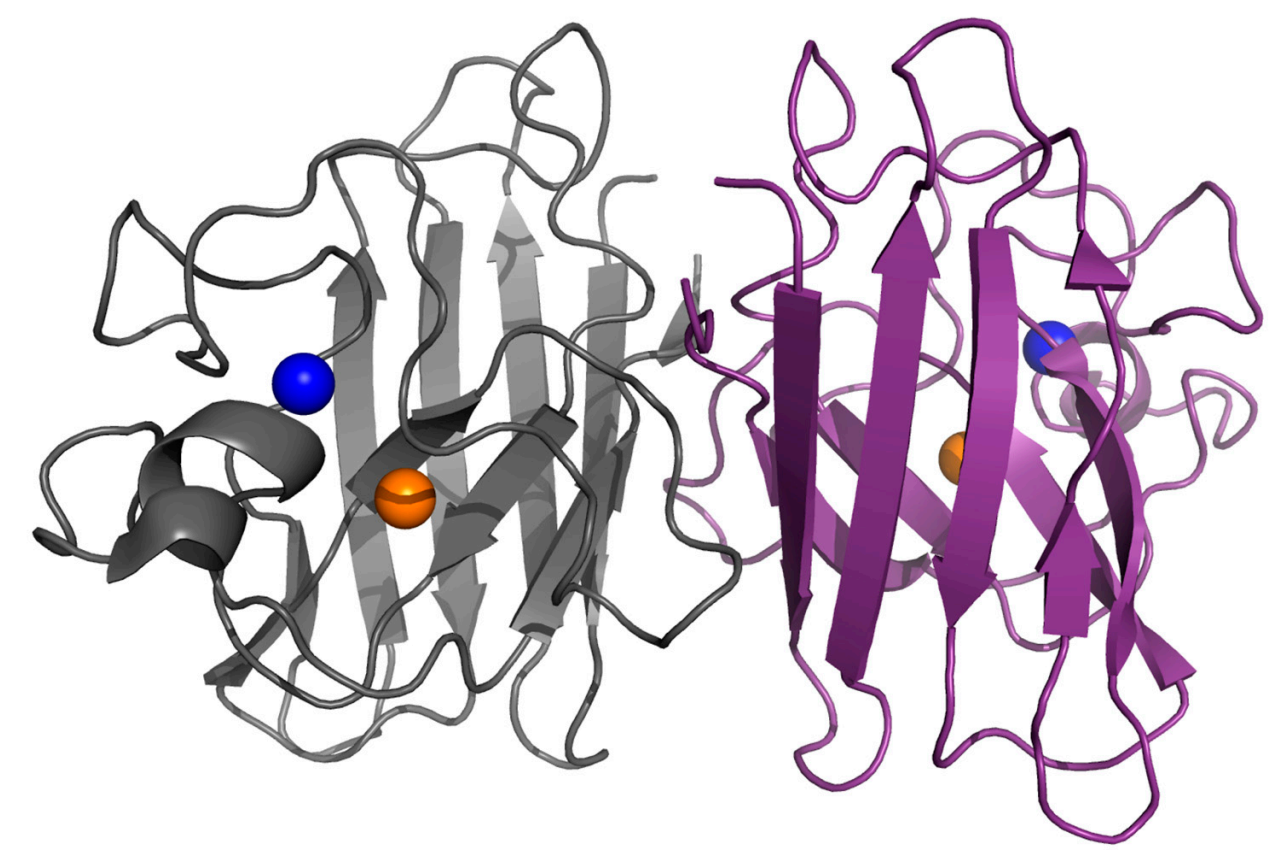

Figure 1. Dimeric SOD1. Structure of human dimeric copper-zinc superoxide dismutase (PDB code: 113n). The copper and zinc ions are represented in orange and blue respectively.

This review discusses the role of metal binding in the aggregation process of SOD1 in familial and sporadic ALS. In addition, we report recent advances on the role of aberrant metal coordination in promoting SOD1 aggregation, highlighting the influence of metal ion homeostasis in pathologic aggregation processes.

\section{Structure, Folding and Stability in SOD1}

SOD1 is a ubiquitous protein that functions as a primary antioxidant by catalyzing the disproportionation of superoxide radicals to hydrogen peroxide and molecular oxygen. The homodimeric protein is localized predominantly in the cytoplasm, but it is also found in other cellular compartments including the nucleus, endoplasmic reticulum and mitochondria [37,38]. The human enzyme is a 32-kDa homodimer and each subunit binds one $\mathrm{Cu}^{2+}$ and $\mathrm{Zn}^{2+}$ in a binuclear site (Figure 1). SOD1 is a 153-residue polypeptide folded into an eight-stranded beta-barrel motif flanked by two major loops, the "electrostatic" and "zinc" loops that together shape the active site pocket. The beta-barrel fold is a fundamental property of the polypeptide and it can be observed even in the absence of metals and disulfide bonds. $\mathrm{Zn}^{2+}$ is coordinated to three histidine and an aspartic residue in the zinc loop which is linked to the $\beta$-barrel by an intra-subunit disulfide bridge (Figure 2). 


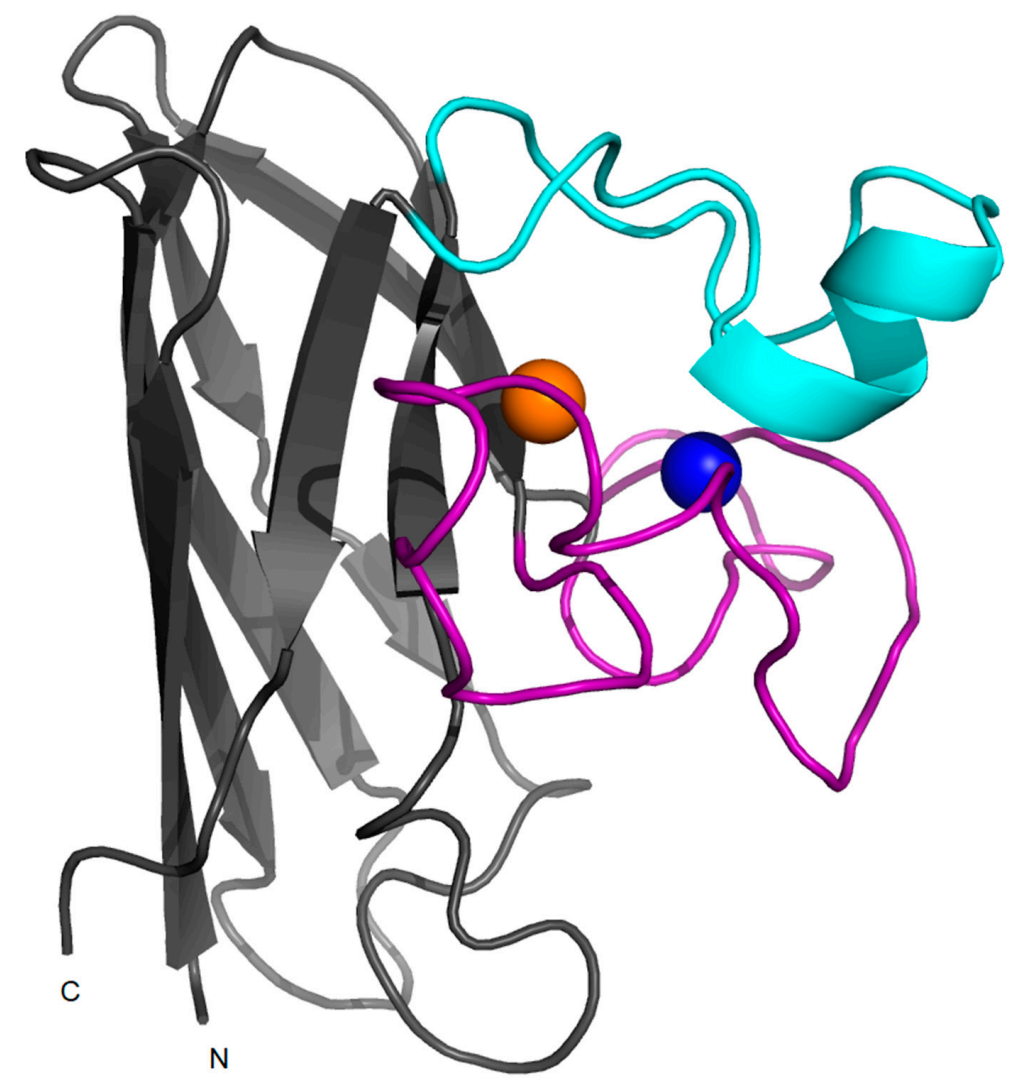

Figure 2. Monomeric SOD1. Structure of a monomer of human wild-type SOD1 (PDB code: 113n) in which copper and zinc ions are represented in orange and blue respectively. The electrostatic loop is shown in cyan and the zinc-loop is shown in magenta.

Zinc binding plays roles in both maintaining the catalytic activity over a wide $\mathrm{pH}$ range and in stabilizing the structure of SOD1 [13,39]. One of the zinc-coordinated histidines is simultaneously coordinated to the copper (in the cupric ion state) by an imidazole side chain and, together with other three histidine residues, keeps the copper in a distorted square planar geometry. The copper ion is responsible for the catalytic activity as, switching between the cupric and cuprous states, it generates hydrogen peroxide and molecular dioxygen from superoxide dismutation. Interestingly, while all the residues that coordinate zinc belong to a flexible loop region, three of the four copper ligands lay in $\beta$-strands that are structured even in the absence of metals [13,39-41]. In the absence of coordinated $\mathrm{Cu}^{2+}$ and $\mathrm{Zn}^{2+}$, the $\beta$-barrel and the dimer interface remain intact but the loops result more disordered. While the mechanism of zinc acquisition by SOD1 in vivo is still unclear, copper is inserted by a copper chaperone (CCS) concomitantly with the formation of an intrasubunit disulfide bond [42-45]. This may not be the only mechanism in humans, since SOD1 in mammalian systems can acquire copper also via a CCS-independent mechanism [46].

A key feature of SOD1 structure is the strong contribution of the post-translational modifications to its stability. Indeed, the maturation of the human SOD1 consists of the following steps: N-terminal acetylation (common to most eukaryotic cytoplasmic proteins), the insertion of copper and zinc ions, the formation of a disulfide bond in each subunit, and dimerization [43,44,47]. These steps are likely to be mutually dependent in vivo as the oligomeric state of SOD1 in vitro is dependent on the metalation state and cysteine residues. In particular, it has been shown that wild-type SOD1 is monomeric only in the disulfide-reduced, metal-free apo-state while disulfide bond formation or the binding of a single metal ion (copper or zinc) in the disulfide-reduced state lead to dimer formation. Likewise, the binding of zinc and/or copper has been shown to stabilize the disulfide bond from reduction [48-50]. SOD1 is an unusual protein able to maintain the disulfide bond even in the reducing environment 
of the cytoplasm and the native intrasubunit disulfide bond is known to contribute to its enzymatic activity [51]. Thus, the metal cofactors, by modulating the status of the disulfide bond, contribute to both the enzymatic activity and structural integrity of SOD1.

The contribution of the different post-translational modifications on the stabilization of SOD1 structure has been studied by complementary biophysical techniques. In particular, a study performed by differential scanning calorimetry revealed for the disulfide-reduced, monomeric apoprotein a $T_{\mathrm{m}}$ of $42{ }^{\circ} \mathrm{C}$; for the more stable dimeric form a $\mathrm{T}_{\mathrm{m}}$ of $52^{\circ} \mathrm{C}$; and for the disulfide-reduced dimeric form a $T_{\mathrm{m}}$ of $58^{\circ} \mathrm{C}$ obtained by binding one zinc per dimer $[49,51]$. The different melting temperatures observed for the two different dimeric SOD1 suggest that the binding of a single zinc to the disulfide-reduced form produce a more stable dimer than that obtained upon disulfide bond formation. Zinc binding has been also shown to increase the stability of the disulfide-intact form of SOD1 [52]. Indeed, this study indicated that the zinc-bound subunit stabilizes the apo subunit as suggested by the increase in its melting temperature from $52{ }^{\circ} \mathrm{C}$ to $60^{\circ} \mathrm{C}$. Thus, the presence of zinc in a single subunit results in stronger intersubunit interactions compared to the apo dimer likely through a tighter dimer interface [52]. The ability of zinc to enhance subunit affinity has been also suggested by analytical centrifugation experiments showing that metallated SOD1 containing 2.9 equivalents of zinc and 0.6 equivalents of copper dissociates to monomers at 2.0-3.0 M guanidinium hydrochloride ( $\mathrm{GdmCl})$ while the apo SOD1 dissociates over the range of 0.5-1.0 M GdmCl [49].

Recently, the zinc binding to apo SOD1 at different stages of its maturation process has been studied by isothermal titration calorimetry. In this study, the authors have characterized the binding of $\mathrm{Zn}^{2+}$ to three models of SOD1: oxidized dimer, oxidized monomer and reduced monomer [53]. Results obtained for the oxidized dimer suggest that $\mathrm{Zn}^{2+}$ binds to the two zinc sites via dissimilar mechanisms and affinities, while $\mathrm{Zn}^{2+}$ binding to the two copper sites in the homodimer occurs through a parallel mechanism with similar energetics. The binding of the first $\mathrm{Zn}^{2+}$ per apoprotein homodimer was reported to have a more profound effect on the protein structure than binding of the second $\mathrm{Zn}^{2+}$, although the two zinc sites are structurally identical in the homodimer [52]. The study of Leal and coworkers calculated asymmetrical binding stoichiometries for binding of $\mathrm{Zn}^{2+}$ to the two zinc binding site suggesting that the initial binding of one zinc to the apo homodimer produces a one-zinc dimer which can then exchange subunits with a second equivalent one-zinc dimer, resulting in a two-zinc homodimer and one apo homodimer [53]. These results suggest that a higher number of $\mathrm{Zn}^{2+}$ participate in the binding to the first high affinity zinc binding site. Differently, isothermogram of $\mathrm{Zn}^{2+}$ binding to the oxidized SOD1 monomer indicated low binding affinity and suggested that the zinc binding affinity to the oxidized monomer is distinct from that of binding to dimer in agreement with recent NMR findings [53,54]. Finally, the investigation of $\mathrm{Zn}^{2+}$ binding to the reduced SOD1 monomer revealed two distinct binding processes. The zinc binding to this SOD1 conformer is particularly significant, as this process has been suggested to occur in the in vivo folding $[55,56]$. The authors suggest that the first binding event corresponds to the interaction with the relatively solvent-exposed zinc site in the SOD1 monomer that thus strongly binds $\mathrm{Zn}^{2+}$ and greatly impacts on SOD1 overall structure, in contrast with the copper site that is yet disorganized $[39,56]$. The second binding event observed could be due to misligation of $\mathrm{Zn}^{2+}$ to the copper site [53]. Indeed, it was shown that exposure of apo SOD1 immature conformers to labile zinc in vitro at physiological $\mathrm{pH}$, generates a SOD1 conformer where $\mathrm{Zn}^{2+}$ is bound to the native zinc site but is also aberrantly bound to the copper site, forming a di-zinc protein $[43,57]$. In contrast, an in cell NMR study revealed that, within the cytoplasm environment, immature SOD1 selectivity coordinates zinc exclusively to the zinc site [58]. In spite of this accurate insertion of zinc, no metallo-chaperone protein that loads zinc into apo SOD1 has yet been found.

The exceptional stability of metallated SOD1 is demonstrated by the ability of this protein to maintain the enzymatic activity even under highly denaturing conditions, such as $6 \mathrm{M} \mathrm{GdmCl}$ or $4 \%$ SDS $[50,59,60]$. This unusual behavior is likely due to the high resistance of holo-SOD1 to unfold completely in the presence of $\mathrm{GdmCl}$, as observed by NMR studies [41]. Indeed, $0.5 \mathrm{M} \mathrm{GdmCl}$ was 
shown to induce only small conformational changes in metallated SOD1 while protein unfolding is achieved only at $\mathrm{GdmCl}$ concentrations of $3.5 \mathrm{M}$ or higher. Interestingly, the unfolded species still possess a residual globular structure with a partly formed hydrophobic core that persists even at $8 \mathrm{M}$ $\mathrm{GdmCl}$ showing that, even in highly denaturing conditions, metallated SOD1 never unfolds to a fully random coil conformation [41]. Apo SOD1 was shown to be less resistant to GdmCl-induced unfolding as it adopts a similar conformation with residual globular structure at $1 \mathrm{M} \mathrm{GdmCl}$. However, for both apo and holo-SOD1, the unfolding process originates from the loops exposed in the structure and proceeds to the $\beta$-strands placed in its core thus explaining why metal binding, disulfide formation and dimerization, providing structure to many loops that connect $\beta$-strands, strongly increase the thermal stability of SOD1 [41].

\section{Role of SOD1 Aggregation in ALS}

Amyotrophic lateral sclerosis is a neurological disease characterized by the selective death of motor neurons leading to progressive muscle atrophy, paralysis, and eventual death [61]. Although it is predominantly a sporadic disease, $10 \%$ of the ALS cases are described as familial (fALS), a dominantly inherited disease in which patients are heterozygous and express both the mutant and the wild-type form of SOD1. Familial forms of the disease are caused by mutations in a number of proteins, of which SOD1 represents the best-studied example. A link between fALS and mutations in the SOD1 gene was first suggested in 1993 [62], and over 100 fALS-linked mutations, distributed throughout the SOD1 gene, are now associated with approximately $20 \%$ of the fALS cases $[13,61,63]$. These are predominantly single amino acid substitutions although deletions, insertions, and C-terminal truncations also occur. Mutations are distributed along the entire length of the polypeptide and affect the onset, duration, and severity of symptoms in afflicted individuals. The pathogenicity of SOD1 mutants has been shown to be due to the gain of a toxic function and not to the loss of the normal function. Indeed, SOD1 knock-out mice do not show any ALS symptoms, whereas transgenic mice, expressing, for example, the fALS-associated mutant G93A human SOD1, develop the symptoms, despite expression of endogenous mouse SOD1 [64-68]. Although many efforts have been addressed to the biophysical characterization of many ALS-related SOD1 mutants, the molecular mechanisms by which the mutations cause fALS are still poorly understood. Investigations on the toxic function acquired by SOD1 have been focused on a prominent feature observed in both human patients and animal models of ALS: the accumulation of SOD1-rich proteinaceous aggregates containing SOD1 in the spinal cord. These observations have led to the hypothesis that SOD1 wild-type or mutants become unstable and misfold to form high-molecular-weight aggregates that are selectively toxic to motor neurons $[69,70]$.

SOD1 aggregation is likely a consequence of the formation of misfolded SOD1 species in the spinal cords of fALS patients as well as presymptomatic mice expressing SOD1 mutants ALS-related [71,72]. Misfolded soluble SOD1 is selectively enriched in the spinal cords of these mice during their lifetime, suggesting that these species are sequestered in protein inclusions when neuronal cells are no longer able to handle the damage induced by misfolded SOD1 [73,74].

SOD1 mutants associated to fALS may be classified into two groups: the "wild-type like" and the "metal binding region" mutants [75]. In the "wild-type like" mutants, the mutations are scattered throughout the $\beta$-barrel of the protein and the zinc levels are very similar to those found in the wild-type protein, i.e., high in zinc but with variable levels of copper. Most of these mutants (i.e., E100K, D101N, D125H, S134N, N139K, D90A and N86S) are nearly indistinguishable from the wild-type protein in terms of stability, metal coordination properties and conformational kinetics as suggested by H/D exchange studies [35,76]. Nonetheless, where data are available, these variants have been shown to aggregate more readily than the wild-type protein in transgenic mouse lines, in cell cultures and in vitro [33,77]. A possible explanation for such behavior is that such mutations could induce minor conformational changes that lead to the formation of a native-like state more susceptible to self-association in vivo. In this type of process, the conformational changes that usually precede 
aggregation, such as local or global unfolding and other structural rearrangements, seem to occur after the formation of the native-like oligomers [78]. In this respect, the "wild-type like" mutations could favor the formation of native-like oligomers that promote protein aggregation. Moreover, other factors as the net surface charge could strongly contribute to protein aggregation propensity. Indeed, several ALS-related SOD1 mutations (i.e., D101N, E100K, N139K and D90A) induce a decrease of the net negative charge of the SOD1 polypeptide. In these mutants, aggregation is likely promoted by the reduction in net charge of the SOD1 polypeptide instead of destabilization of the native state. In addition, it is reasonable that stable SOD1 variants with a lower net charge might interact more readily with anionic membrane surfaces such as those present in the mitochondrial membrane thus inducing cytotoxicity [33].

In the "metal binding region" mutants, the mutations affect the metal binding ligands themselves or elements intimately associated with metal binding. When isolated from the expression systems, these mutants are characterized by very low zinc and copper content $[27,29]$. The occupation of copper and zinc binding sites not only affects the stability of SOD1 but it is also likely to act upon the free energy barrier to unfolding, thus affecting the so-called "kinetic stability" of SOD1 [32,36]. Therefore, the loss of these ions may facilitate partial or global unfolding transitions that may lead to protein misfolding and aggregation. In this respect, metal binding could play a key role in the aggregation process of SOD1 in fALS.

\section{Metal Binding and Aggregation of SOD1 in ALS}

SOD1 is a highly stable homodimeric protein that possesses in each monomer a disulfide bridge as well as a copper/zinc binuclear site. The remarkable stability and the metal-binding abilities of the wild-type SOD1 apoprotein do not seem to be required for the optimization of the superoxide dismutase activity [79]. Instead, it appears that these unique properties evolved to optimize the free-energy landscape of folding, disulfide bond formation, and efficient in vivo metalation of the immature disulfide-reduced nascent SOD1 apoprotein [36]. Particularly relevant in this regard are recent demonstrations of the strong influence of metal ions on the kinetics of SOD1 folding [41,80-82]. In addition, Leinartaite and coworkers have recently demonstrated that $\mathrm{Zn}^{2+}$ catalyzes the folding of apo-SOD1 by transient docking at the native copper site followed by a slower migration to the native zinc site after that latter site has formed [83]. Both metal binding and disulfide bond formation strongly contribute to the high stability of native SOD1 and these post-translational modifications are not independent but linked. Indeed, deficiency in metal binding increases the susceptibility of SOD1 to disulfide reduction [26]. In this respect, the native metalation and, in particular, the correct $\mathrm{Zn}^{2+}$ coordination plays a key role in the regulation of SOD1 folding [52,84].

Interestingly, SOD1 aggregates from transgenic fALS mouse models were found to be metal-deficient and/or lack the disulfide bond, raising the possibility that the in vivo aggregation of SOD1 could involve the immature forms of the protein lacking one or more post-translational modifications [34,72]. In addition, in vitro experiments revealed that the formation of monomeric SOD1 precedes the appearance of visible aggregates [85]. As for both SOD1 wild-type and most ALS-related mutants only the metal-free, disulfide-reduced form is monomeric [13,15,50]; therefore, many studies have been focused on in vitro aggregation of SOD1 lacking the metal cofactors and/or the intramolecular disulfide bond.

Comparison of the structure and mobility of apo-SOD1 and disulfide-oxidized holo-SOD1 suggests partial unfolding of apo-SOD1. Indeed, both the "zinc loop" and the "electrostatic loop" resulted significantly disordered in apo-SOD1 as suggested by X-ray crystallography and H/D exchange studies $[32,86,87]$. In addition, the disulfide-reduced apoprotein in vitro displays an increased surface hydrophobicity and a decreased mobility than the disulfide-oxidized holoprotein and recent molecular dynamics simulations support the hypothesis that local unfolding of the metal-free, disulfide-reduced SOD1 leads to the "building blocks" for SOD1 aggregation [26,88]. 
In vitro studies have shown that, while metalated SOD1 did not form amyloid-like aggregates at neutral $\mathrm{pH}$, either removing metals from SOD1 with its intramolecular disulfide bond intact or reducing the intramolecular disulfide bond of metalated SOD1 was sufficient to promote formation of these aggregates $[27,32,89]$. This vulnerability of the apo-state to self-associate is related with high flexibility and disorder of both zinc and electrostatic loops [86,87]. Demetalated SOD1 formed amyloid-like aggregates in physiological conditions of $\mathrm{pH}$, temperature and ionic strength regardless of the disulfide's redox state suggesting that removal of copper and zinc was sufficient to trigger amyloid formation $[25,27]$.

A significant fraction of wild-type SOD1 has been shown to be incompletely metalated in vivo [90-92], and both incompletely metalated and disulfide-reduced SOD1 are present in transgenic mice expressing various ALS mutants of SOD1 [73,77]. Intriguingly, several studies have shown that the presence of undermetalated and disulfide-reduced SOD1 is exacerbated by the presence of mutations related to ALS. Most of these mutations have been shown to promote amyloid formation in vitro by allowing dissociation of metals from SOD1 at $\mathrm{pH}$ values where metals remain tightly bound to wild-type SOD1, and this effect was most pronounced for the metal-binding-region mutants $[25,91]$. In this respect, the metal-binding-region mutations may promote amyloid aggregation in SOD1 by facilitating the loss of metals and/or by making the intramolecular disulfide bond more susceptible to reduction. In addition, several wild-type-like mutants, including the severe A4V and L38V, were shown to have lower zinc affinities than the wild-type protein in the presence of $2 \mathrm{M}$ urea [92]. These observations suggest that, in a physiological context, loss of metals could be promoted by a local acidic environment or by other cellular stresses, and this would occur more readily with SOD1 mutants. Alternatively, newly synthesized mutant SOD1 proteins may form amyloid aggregates before metals are coordinated.

Although it is now widely accepted that low metalation could be a triggering factor in the ALS-related aggregation of SOD1, many studies have been recently focused on the role of aberrant metal binding in the aggregation process of SOD1. Indeed, SOD1 metal binding sites possess very different geometries, ligand types, labilities, and stabilities, and formation of non-native metal binding has been shown to occur in vitro $[36,53,83,93]$. In addition, mismetalation has been shown to trigger SOD1 toxic deposition [53]. For instance, zinc is known to have a promiscuous behavior towards SOD1 metal binding sites, being able to jump between the copper and zinc ligands through a parallel mechanism with undistinguishable energetics [83]. At the early stages of SOD1 folding, $\mathrm{Zn}^{2+}$ binds to the copper site accelerating the folding reaction. As the reaction progresses zinc binding site, which structures late in the folding and process, organized $\mathrm{Zn}^{2+}$ is transferred to its most thermodynamically favorable condition at the high affinity zinc site. If the zinc ligands are mutated, copper ligands can initially coordinate the non-native zinc ion; however, without the structural support of the loaded zinc site the protein misfolds and has an increased propensity to aggregate [83]. Thus, the aberrant zinc binding to immature conformers of metal-free SOD1 triggers the formation of protein aggregates and, considering that $\mathrm{Zn}^{2+}$ is upregulated in ALS affected motor neurons, the aberrant zinc-protein interactions may be one of the factors contributing to the onset of SOD1 pathological aggregation [53]. Likewise, $\mathrm{Ni}^{2+}$ can bind to both metal binding sites of apo-SOD1 in vitro and this non-native binding has been shown to promote SOD1 misfolding and aggregation [36]. Also $\mathrm{Ca}^{2+}$ has been shown to bind SOD1 under physiological $\mathrm{pH}$ and induce conformational changes that promote aggregation in SOD1 [93]. As a ligand, $\mathrm{Ca}^{2+}$ is particularly versatile because it binds sites with irregular geometry, thus facilitating its nonspecific association to proteins [94]. In agreement, a bound $\mathrm{Ca}^{2+}$ ion was described in a crystal structure of a SOD1 clinical mutant although sequence analysis and bioinformatics failed to identify any canonical $\mathrm{Ca}^{2+}$ binding motif within SOD1 [95]. As $\mathrm{Ca}^{2+}$ is increased in ALS and is particularly abundant in the specific motor neurons affected in this disease, it may be considered between the factors contributing to the onset of SOD1 in vivo aggregation.

Taken together these data provide evidence that metal binding, in addition of being necessary for SOD1 enzymatic activity, is a key factor in the aggregation process of SOD1. In particular, 
both demetalation and aberrant metal binding have been shown to promote misfolding and aggregation in SOD1 suggesting a possible role of metal binding in SOD1 pathological aggregation. This modulation effect by a metal ion has been also demonstrated for other proteins involved in neurodegenerative disorders, highlighting the influence of the chemical neuronal environment with respect to metal ion homeostasis in pathologic aggregation processes [96].

\section{Outlook}

Protein misfolding and aggregation are common hallmarks in many neurodegenerative diseases. The propensity of a protein to aggregate is a complex property reflecting a combination of different biophysical and physico-chemical parameters such as net charge, hydrophobicity, native state stability and intrinsic $\beta$-structure as well as post translational modifications [97,98]. Copper-zinc superoxide dismutase, due to its complexity, is a suitable model for dissecting the role of physico-chemical properties on the aggregation propensity of a polypeptide chain. In particular, SOD1 is an extremely stable protein when fully assembled, but it is rather unstable and prone to aggregation in its metal-free form. As SOD1 is implicated in the formation of proteinaceous toxic aggregates in the affected motor neurons of familial and sporadic forms of ALS, metals are suggested to potentially modulate toxic protein deposition in ALS as well as in other neurodegenerative conditions. In addition, recent advances indicating that aberrant metal coordination is also able to promote SOD1 aggregation. This condition is likely to occur in vivo as perturbation on the intracellular concentrations of metal ions is known to be involved in neurodegenerative diseases, highlighting the influence of metal ion homeostasis in pathologic aggregation processes. Indeed, significantly increased level of zinc and copper ions as well as the other metal ions was reported in ventral areas of spinal cords from sporadic ALS cases suggesting a key role of metal dyshomeostasis in the pathogenesis of SOD1-ALS [99,100]. Interestingly, the treatment of mice expressing SOD pathological mutants with metal chelators was able to delay the disease onset and extend the mice lifespan [100-102]. The modulation effect by metal ions has been also demonstrated for other proteins involved in neurodegenerative disorders, highlighting the influence of the chemical neuronal environment, with regard to metal ion homeostasis, in pathologic aggregation processes. In this respect, normalizing metal dyshomeostasis in pathological conditions could be a key to developing therapeutics for these devastating diseases.

Acknowledgments: Publication fees were covered by the grant "Finanziamento per Rientro dei Cervelli "Rita Levi Montalcini" from Italian Minister of University and Research (MIUR).

Author Contributions: Conceived and coordinate the study: C.I. Wrote the paper: C.I. and I.S.

Conflicts of Interest: The authors declare no conflict of interest.

\section{References}

1. Stefani, M. Protein misfolding and aggregation: New examples in medicine and biology of the dark side of the protein world. Biochim. Biophys. Acta 2004, 1739, 5-25. [CrossRef] [PubMed]

2. Bucciantini, M.; Giannoni, E.; Chiti, F.; Baroni, F.; Formigli, L.; Zurdo, J.; Taddei, N.; Ramponi, G.; Dobson, C.M.; Stefani, M. Inherent toxicity of aggregates implies a common mechanism for protein misfolding diseases. Nature 2002, 416, 507-511. [CrossRef] [PubMed]

3. Evangelisti, E.; Cascella, R.; Becatti, M.; Marrazza, G.; Dobson, C.M.; Chiti, F.; Stefani, M.; Cecchi, C. Binding affinity of amyloid oligomers to cellular membranes is a generic indicator of cellular dysfunction in protein misfolding diseases. Sci. Rep. 2016, 6, 32721. [CrossRef] [PubMed]

4. Serpell, L.C. Alzheimer's amyloid fibrils: Structure and assembly. Biochim. Biophys. Acta 2000, 1502, 16-30. [CrossRef]

5. Fitzpatrick, A.W.; Debelouchina, G.T.; Bayro, M.J.; Clare, D.K.; Caporini, M.A.; Bajaj, V.S.; Jaroniec, C.P.; Wang, L.; Ladizhansky, V.; Müller, S.A.; et al. Atomicstructure and hierarchicalassembly of a cross- $\beta$ amyloidfibril. Proc. Natl. Acad. Sci. USA 2013, 110, 5468-5473. [CrossRef] [PubMed] 
6. Gaggelli, E.; Kozlowski, H.; Valensin, D.; Valensin, G. Copper homeostasis and neurodegenerative disorders (Alzheimer's, prion, and Parkinson's diseases and amyotrophic lateral sclerosis). Chem. Rev. 2006, 106, 1995-2044. [CrossRef] [PubMed]

7. DeToma, A.S.; Salamekh, S.; Ramamoorthy, A.; Lim, M.H. Misfolded proteins in Alzheimer's disease and type II diabetes. Chem. Soc. Rev. 2012, 41, 608-621. [CrossRef] [PubMed]

8. Brender, J.R.; Salamekh, S.; Ramamoorthy, A. Membrane disruption and early events in the aggregation of the diabetes related peptide IAPP from a molecular perspective. Acc. Chem. Res. 2012, 45, 454-462. [CrossRef] [PubMed]

9. Braymer, J.J.; Choi, J.S.; DeToma, A.S.; Wang, C.; Nam, K.; Kampf, J.W.; Ramamoorthy, A.; Lim, M.H. Development of bifunctional stilbene derivatives for targeting and modulating metal-amyloid- $\beta$ species. Inorg. Chem. 2011, 50, 10724-10734. [CrossRef] [PubMed]

10. Salamekh, S.; Brender, J.R.; Hyung, S.J.; Nanga, R.P.; Vivekanandan, S.; Ruotolo, B.T.; Ramamoorthy, A. A two-site mechanism for the inhibition of IAPP amyloidogenesis by zinc. J. Mol. Biol. 2011, 410, $294-306$. [CrossRef] [PubMed]

11. Choi, J.S.; Braymer, J.J.; Nanga, R.P.; Ramamoorthy, A.; Lim, M.H. Design of small molecules that target metal-A $\beta$ species and regulate metal-induced $\mathrm{A} \beta$ aggregation and neurotoxicity. Proc. Natl. Acad. Sci. USA 2010, 107, 21990-21995. [CrossRef] [PubMed]

12. Manto, M. Abnormal copper homeostasis: Mechanisms and roles in neurodegeneration. Toxics 2014, 2, 327-345. [CrossRef]

13. Valentine, J.S.; Doucette, P.A.; Potter, S.Z. Copper-zinc superoxide dismutase and amyotrophic lateral sclerosis. Annu. Rev. Biochem. 2005, 74, 563-593. [CrossRef] [PubMed]

14. Culotta, V.C.; Yang, M.; O'Halloran, T.V. Activation of superoxide dismutases: Putting the metal to the pedal. Biochim. Biophys. Acta 2006, 1763, 747-758. [CrossRef] [PubMed]

15. Banci, L.; Bertini, I.; Boca, M.; Girotto, S.; Martinelli, M.; Valentine, J.S.; Vieru, M. SOD1 and amyotrophic lateral sclerosis: Mutations and oligomerization. PLoS ONE 2008, 3, e1677. [CrossRef] [PubMed]

16. Rowland, L.P.; Shneider, N.A. Amyotrophic lateral sclerosis. N. Engl. J. Med. 2001, 344, 1688-1700. [CrossRef] [PubMed]

17. Kabashi, E.; Valdmanis, P.N.; Dion, P.; Rouleau, G.A. Oxidized/misfolded superoxide dismutase-1: The cause of all amyotrophic lateral sclerosis? Ann. Neurol. 2007, 62, 553-559. [CrossRef] [PubMed]

18. Gruzman, A.; Wood, W.L.; Alpert, E.; Prasad, M.D.; Miller, R.G.; Rothstein, J.D.; Bowser, R.; Hamilton, R.; Wood, T.D.; Cleveland, D.W.; et al. Common molecular signature in SOD1 for both sporadic and familial amyotrophic lateral sclerosis. Proc. Natl. Acad. Sci. USA 2007, 104, 12524-12529. [CrossRef] [PubMed]

19. Chattopadhyay, M.; Valentine, J.S. Aggregation of copper-zinc superoxide dismutase in familial and sporadic ALS. Antioxid. Redox Signal. 2009, 11, 1603-1614. [CrossRef] [PubMed]

20. Rotunno, M.S.; Bosco, D.A. An emerging role for misfolded wild-type SOD1 in sporadic ALS pathogenesis. Front. Cell. Neurosci. 2013, 7, 253. [CrossRef] [PubMed]

21. Forsberg, K.; Andersen, P.M.; Marklund, S.L.; Brannstrom, T. Glial nuclear aggregates of superoxide dismutase-1 are regularly present in patients with amyotrophic lateral sclerosis. Acta Neuropathol. 2011, 121, 623-634. [CrossRef] [PubMed]

22. Furukawa, Y. Pathological roles of wild-type $\mathrm{Cu}, \mathrm{Zn}$-superoxide dismutase in amyotrophic lateral sclerosis. Neurol. Res. Int. 2012, 2012, 323261. [CrossRef] [PubMed]

23. Guareschi, S.; Cova, E.; Cereda, C.; Ceroni, M.; Donetti, E.; Bosco, D.A.; Trotti, D.; Pasinelli, P. An over-oxidized form of superoxide dismutase found in sporadic amyotrophic lateral sclerosis with bulbar onset shares a toxic mechanism with mutant SOD1. Proc. Natl. Acad. Sci. USA 2012, 109, 5074-5079. [CrossRef] [PubMed]

24. Banci, L.; Bertini, I.; Durazo, A.; Girotto, S.; Gralla, E.B.; Martinelli, M.; Valentine, J.S.; Vieru, M.; Whitelegge, J.P. Metal-free superoxide dismutase forms soluble oligomers under physiological conditions: A possible general mechanism for familial ALS. Proc. Natl. Acad. Sci. USA 2007, 104, 11263-11267. [CrossRef] [PubMed]

25. Oztug Durer, Z.A.; Cohlberg, J.A.; Dinh, P.; Padua, S.; Ehrenclou, K.; Downes, S.; Tan, J.K.; Nakano, Y.; Bowman, C.J.; Hoskins, J.L.; et al. Loss of metal ions, disulfide reduction and mutations related to familial ALS promote formation of amyloid-like aggregates from superoxide dismutase. PLoS ONE 2009, 4, e5004. [CrossRef] [PubMed] 
26. Tiwari, A.; Liba, A.; Sohn, S.H.; Seetharaman, S.V.; Bilsel, O.; Matthews, C.R.; Hart, P.J.; Valentine, J.S.; Hayward, L.J. Metal deficiency increases aberrant hydrophobicity of mutant superoxide dismutases that cause amyotrophic lateral sclerosis. J. Biol. Chem. 2009, 284, 27746-27758. [CrossRef] [PubMed]

27. Sheng, Y.; Chattopadhyay, M.; Whitelegge, J.; Valentine, J.S. SOD1 aggregation and ALS: Role of metallation states and disulfide status. Curr. Top. Med. Chem. 2012, 12, 2560-2572. [CrossRef] [PubMed]

28. Sirangelo, I.; Vella, F.M.; Irace, G.; Manco, G.; Iannuzzi, C. Glycation in demetalated superoxide dismutase 1 prevents amyloid aggregation and produces cytotoxic ages adducts. Front. Mol. Biosci. 2016, 3, 55. [CrossRef] [PubMed]

29. Ayers, J.I.; McMahon, B.; Gill, S.; Lelie, H.L.; Fromholt, S.; Brown, H.; Valentine, J.S.; Whitelegge, J.P.; Borchelt, D.R. Relationship between mutant $\mathrm{Cu} / \mathrm{Zn}$ superoxide dismutase 1 maturation and inclusion formation in cell models. J. Neurochem. 2017, 140, 140-150. [CrossRef] [PubMed]

30. Rakhit, R.; Cunningham, P.; Furtos-Matei, A.; Dahan, S.; Qi, X.F.; Crow, J.P.; Cashman, N.R.; Kondejewski, L.H.; Chakrabartty, A. Oxidation-induced misfolding and aggregation of superoxide dismutase and its implications for amyotrophic lateral sclerosis. J. Biol. Chem. 2002, 277, 47551-47556. [CrossRef] [PubMed]

31. Wang, J.; Xu, G.; Gonzales, V.; Coonfield, M.; Fromholt, D.; Copeland, N.G.; Jenkins, N.A.; Borchelt, D.R. Fibrillar inclusions and motor neuron degeneration in transgenic mice expressing superoxide dismutase 1 with a disrupted copper-binding site. Neurobiol. Dis. 2002, 10, 128-138. [CrossRef] [PubMed]

32. Banci, L.; Bertini, I.; Boca, M.; Calderone, V.; Cantini, F.; Girotto, S.; Vieru, M. Structural and dynamic aspects related to oligomerization of apo SOD1 and its mutants. Proc. Natl. Acad. Sci. USA 2009, 106, 6980-6985. [CrossRef] [PubMed]

33. Shaw, B.F.; Valentine, J.S. How do ALS-associated mutations in superoxide dismutase 1 promote aggregation of the protein? Trends Biochem. Sci. 2007, 32, 78-85. [CrossRef] [PubMed]

34. Lelie, H.L.; Liba, A.; Bourassa, M.W.; Chattopadhyay, M.; Chan, P.K.; Gralla, E.B.; Miller, L.M.; Borchelt, D.R.; Valentine, J.S.; Whitelegge, J.P. Copper and zincmetallation status of copper-zincsuperoxidedismutase from amyotrophiclateralsclerosistransgenic mice. J. Biol. Chem. 2011, 286, 2795-2806. [CrossRef] [PubMed]

35. Chan, P.K.; Chattopadhyay, M.; Sharma, S.; Souda, P.; Gralla, E.B.; Borchelt, D.R.; Whitelegge, J.P.; Valentine, J.S. Structural similarity of wild-type and ALS-mutant superoxide dismutase-1 fibrils using limited proteolysis and atomic force microscopy. Proc. Natl. Acad. Sci. USA 2013, 110, 10934-10939. [CrossRef] [PubMed]

36. Ming, L.J.; Valentine, J.S. Insights into SOD1-linked amyotrophic lateral sclerosis from NMR studies of $\mathrm{Ni}^{2+}$ and other metal-ion-substituted wild-type copper-zinc superoxide dismutases. J. Biol. Inorg. Chem. 2014, 19, 647-657. [CrossRef] [PubMed]

37. Kikuchi, H.; Almer, G.; Yamashita, S.; Guégan, C.; Nagai, M.; Xu, Z.; Sosunov, A.A.; McKhann, G.M.; Przedborski, S. Spinal cord endoplasmic reticulum stress associated with a microsomal accumulation of mutant superoxide dismutase-1 in an ALS model. Proc. Natl. Acad. Sci. USA 2006, 103, 6025-6030. [CrossRef] [PubMed]

38. Shi, P.; Gal, J.; Kwinter, D.M.; Liu, X.; Zhu, H. Mitochondrial dysfunction in amyotrophic lateral sclerosis. Biochim. Biophys. Acta 2010, 1802, 45-51. [CrossRef] [PubMed]

39. Banci, L.; Bertini, I.; Cramaro, F.; Del Conte, R.; Viezzoli, M.S. Solution structure of apo Cu, Zn superoxidedismutase: Role of metal ions in proteinfolding. Biochemistry 2003, 42, 9543-9553. [CrossRef] [PubMed]

40. Bordo, D.; Djinović, K.; Bolognesi, M. Conserved patterns in the $\mathrm{Cu}, \mathrm{Zn}$ superoxide dismutase family. J. Mol. Biol. 1994, 238, 366-386. [CrossRef] [PubMed]

41. Assfalg, M.; Banci, L.; Bertini, I.; Turano, P.; Vasos, P.R. Superoxide dismutase folding/unfolding pathway: Role of the metal ions in modulating structural and dynamical features. J. Mol. Biol. 2003, 330, 145-158. [CrossRef]

42. Caruano-Yzermans, A.L.; Bartnikas, T.B.; Gitlin, J.D. Mechanisms of the copper-dependent turnover of the copper chaperone for superoxide dismutase. J. Biol. Chem. 2006, 281, 13581-13587. [CrossRef] [PubMed]

43. Banci, L.; Barbieri, L.; Bertini, I.; Cantini, F.; Luchinat, E. In-cell NMR in E. coli to monitor maturationsteps of hSOD1. PLoS ONE 2011, 6, e23561. [CrossRef] [PubMed]

44. Banci, L.; Bertini, I.; Cantini, F.; Kozyreva, T.; Massagni, C.; Palumaa, P.; Rubino, J.T.; Zovo, K. Human superoxide dismutase 1 (hSOD1) maturation through interaction with human copper chaperone for SOD1 (hCCS). Proc. Natl. Acad. Sci. USA 2012, 109, 13555-13560. [CrossRef] [PubMed] 
45. Furukawa, Y.; Torres, A.S.; O'Halloran, T.V. Oxygen-induced maturation of SOD1: A key role for disulfide formation by the copper chaperone CCS. EMBO J. 2004, 23, 2872-2881. [CrossRef] [PubMed]

46. Carroll, M.C.; Girouard, J.B.; Ulloa, J.L.; Subramaniam, J.R.; Wong, P.C.; Valentine, J.S.; Culotta, V.C. Mechanisms for activating $\mathrm{Cu}$ - and $\mathrm{Zn}$-containing superoxide dismutase in the absence of the CCS $\mathrm{Cu}$ chaperone. Proc. Natl. Acad. Sci. USA 2004, 101, 5964-5969. [CrossRef] [PubMed]

47. Hörnberg, A.; Logan, D.T.; Marklund, S.L.; Oliveberg, M. The coupling between disulphide status, metallation and dimer interface strength in $\mathrm{Cu} / \mathrm{Zn}$ superoxide dismutase. J. Mol. Biol. 2007, 365, 333-342. [CrossRef] [PubMed]

48. Arnesano, F.; Banci, L.; Bertini, I.; Martinelli, M.; Furukawa, Y.; O’Halloran, T.V. The unusually stable quaternary structure of human $\mathrm{Cu}, \mathrm{Zn}$-superoxide dismutase 1 is controlled by both metal occupancy and disulfide status. J. Biol. Chem. 2004, 279, 47998-48003. [CrossRef] [PubMed]

49. Doucette, P.A.; Whitson, L.J.; Cao, X.; Schirf, V.; Demeler, B.; Valentine, J.S.; Hansen, J.C.; Hart, P.J. Dissociation of human copper-zinc superoxide dismutase dimers using chaotrope and reductant. Insights into the molecular basis for dimer stability. J. Biol. Chem. 2004, 279, 54558-54566. [CrossRef] [PubMed]

50. Lindberg, M.J.; Normark, J.; Holmgren, A.; Oliveberg, M. Folding of human superoxide dismutase: Disulfide reduction prevents dimerization and produces marginally stable monomers. Proc. Natl. Acad. Sci. USA 2004, 101, 15893-15898. [CrossRef] [PubMed]

51. Furukawa, Y.; O'Halloran, T.V. Amyotrophic lateral sclerosis mutations have the greatest destabilizing effect on the apo- and reduced form of SOD1, leading to unfolding and oxidative aggregation. J. Biol. Chem. 2005, 280, 17266-17274. [CrossRef] [PubMed]

52. Potter, S.Z.; Zhu, H.; Shaw, B.F.; Rodriguez, J.A.; Doucette, P.A.; Sohn, S.H.; Durazo, A.; Faull, K.F.; Gralla, E.B.; Nersissian, A.M.; et al. Binding of a single zinc ion to one subunit of copper-zinc superoxide dismutase apoprotein substantially influences the structure and stability of the entire homodimeric protein. J. Am. Chem. Soc. 2007, 129, 4575-4583. [CrossRef] [PubMed]

53. Leal, S.S.; Cristóvão, J.S.; Biesemeier, A.; Cardoso, I.; Gomes, C.M. Aberrant zinc binding to immature conformers of metal-free copper-zinc superoxide dismutase triggers amorphous aggregation. Metallomics 2015, 7, 333-346. [CrossRef] [PubMed]

54. Luchinat, E.; Barbieri, L.; Rubino, J.T.; Kozyreva, T.; Cantini, F.; Banci, L. In-cell NMR reveals potential precursor of toxic species from SOD1 fALS mutants. Nat. Commun. 2014, 5, 5502. [CrossRef] [PubMed]

55. Lamb, A.L.; Torres, A.S.; O'Halloran, T.V.; Rosenzweig, A.C. Heterodimeric structure of superoxide dismutase in complex with its metallochaperone. Nat. Struct. Biol. 2001, 8, 751-755. [CrossRef] [PubMed]

56. Banci, L.; Bertini, I.; Cantini, F.; D'Onofrio, M.; Viezzoli, M.S. Structure and dynamics of copper-free SOD: The protein before binding copper. Protein Sci. 2002, 11, 2479-2492. [CrossRef] [PubMed]

57. Valentine, J.S.; Pantoliano, M.W.; McDonnell, P.J.; Burger, A.R.; Lippard, S.J. pH-dependent migration of copper(II) to the vacant zinc-binding site of zinc-free bovine erythrocyte superoxide dismutase. Proc. Natl. Acad. Sci. USA 1979, 76, 4245-4249. [CrossRef] [PubMed]

58. Banci, L.; Barbieri, L.; Luchinat, E.; Secci, E. Visualization of redox-controlled protein fold in living cells. Chem. Biol. 2013, 20, 747-752. [CrossRef] [PubMed]

59. Forman, H.J.; Fridovich, I. On the stability of bovine superoxide dismutase: The effect of metals. J. Biol. Chem. 1973, 248, 2645-2649. [PubMed]

60. Stathopulos, P.B.; Rumfeldt, J.A.; Karbassi, F.; Siddall, C.A.; Lepock, J.R.; Meiering, E.M. Calorimetric analysis of thermodynamic stability and aggregation for apo and holo amyotrophic lateral sclerosis-associated Gly-93 mutants of superoxide dismutase. J. Biol. Chem. 2006, 281, 6184-6193. [CrossRef] [PubMed]

61. Bruijn, L.I.; Miller, T.M.; Cleveland, D.W. Unraveling the mechanisms involved in motor neuron degeneration in ALS. Annu. Rev. Neurosci. 2004, 27, 723-749. [CrossRef] [PubMed]

62. Rosen, D.R. Mutation in $\mathrm{Cu}, \mathrm{Zn}$ superoxide dismutase gene are associated with familial amyotrophyc lateral sclerosis. Nature 1993, 362, 59-62. [CrossRef] [PubMed]

63. Andersen, P.M. Amyotrophic lateral sclerosis associated with mutations in the CuZn superoxide dismutase gene. Curr. Neurol. Neurosci. Rep. 2006, 6, 37-46. [CrossRef] [PubMed]

64. Boillée, S.; Velde, C.V.; Cleveland, D.W. ALS: A disease of motor neurons and their nonneuronal neighbors. Neuron 2006, 52, 39-59. [CrossRef] [PubMed] 
65. Gurney, M.E.; Pu, H.; Chiu, A.Y.; Dal Canto, M.C.; Polchow, C.Y.; Alexander, D.D.; Caliendo, J.; Hentati, A.; Kwon, Y.W.; Deng, H.X. Motor neuron degeneration in mice that express a human Cu, Zn superoxide dismutase mutation. Science 1994, 264, 1772-1775. [CrossRef] [PubMed]

66. Reaume, A.G.; Elliott, J.L.; Hoffman, E.K.; Kowall, N.W.; Ferrante, R.J.; Siwek, D.R.; Wilcox, H.M.; Flood, D.G.; Beal, M.F.; Brown, R.H. Motor neurons in $\mathrm{Cu} / \mathrm{Zn}$ superoxide dismutase-deficient mice develop normally but exhibit enhanced cell death after axonal injury. Nat. Genet. 1996, 13, 43-47. [CrossRef] [PubMed]

67. Wong, P.C.; Pardo, C.A.; Borchelt, D.R.; Lee, M.K.; Copeland, N.G.; Jenkins, N.A.; Sisodia, S.S.; Cleveland, D.W.; Price, D.L. An adverse property of a familial ALS-linked SOD1 mutation causes motor neuron disease characterized by vacuolar degeneration of mitochondria. Neuron 1995, 14, 1105-1116. [CrossRef]

68. Tu, P.H.; Raju, P.; Robinson, K.A.; Gurney, M.E.; Trojanowski, J.Q.; Lee, V.M. Transgenic mice carrying a human mutant superoxide dismutase transgene develop neuronal cytoskeletal pathology resembling human amyotrophic lateral sclerosis lesions. Proc. Natl. Acad. Sci. USA 1996, 93, 3155-3160. [CrossRef] [PubMed]

69. Bruijn, L.I.; Houseweart, M.K.; Kato, S.; Anderson, K.L.; Anderson, S.D. Aggregation and motor neuron toxicity of an ALS-linked SOD1 mutant independent from wild-type SOD1. Science 1998, 281, 1851-1854. [CrossRef] [PubMed]

70. Borchelt, D.R.; Lee, M.K.; Slunt, H.S.; Guarnieri, M.; Xu, Z.; Wong, P.C.; Brown, R.H.; Price, D.L.; Sisodia, S.S.; Cleveland, D.W. Superoxide dismutase 1 with mutations linked to familial amyotrophic lateral sclerosis possesses significant activity. Proc. Natl. Acad. Sci. USA 1994, 91, 8292-8296. [CrossRef] [PubMed]

71. Johnston, J.A.; Dalton, M.J.; Gurney, M.E.; Kopito, R.R. Formation of high molecular weight complexes of mutant $\mathrm{Cu}, \mathrm{Zn}$-superoxide dismutase in a mouse model for familial amyotrophic lateral sclerosis. Proc. Natl. Acad. Sci. USA 2000, 97, 12571-12576. [CrossRef] [PubMed]

72. Jonsson, P.A.; Ernhill, K.; Andersen, P.M.; Bergemalm, D.; Brännström, T.; Gredal, O.; Nilsson, P.; Marklund, S.L. Minute quantities of misfolded mutant superoxide dismutase-1 cause amyotrophic lateral sclerosis. Brain 2004, 127 Pt 1, 73-88. [CrossRef] [PubMed]

73. Zetterström, P.; Stewart, H.G.; Bergemalm, D.; Jonsson, P.A.; Graffmo, K.S.; Andersen, P.M.; Brännström, T.; Oliveberg, M.; Marklund, S.L. Soluble misfolded subfractions of mutant superoxide dismutase-1s are enriched in spinal cords throughout life in murine ALS models. Proc. Natl. Acad. Sci. USA 2007, 104, 14157-14162. [CrossRef] [PubMed]

74. Brotherton, T.E.; Li, Y.; Glass, J.D. Cellular toxicity of mutant SOD1 protein is linked to an easily soluble, non-aggregated form in vitro. Neurobiol. Dis. 2013, 49, 49-56. [CrossRef] [PubMed]

75. Hayward, L.J.; Rodriguez, J.A.; Kim, J.W.; Tiwari, A.; Goto, J.J.; Cabelli, D.E.; Valentine, J.S.; Brown, R.H. Decreased metallation and activity in subsets of mutant superoxide dismutases associated with familial amyotrophic lateral sclerosis. J. Biol. Chem. 2002, 277, 15923-15931. [CrossRef] [PubMed]

76. Rodriguez, J.A.; Shaw, B.F.; Durazo, A.; Sohn, S.H.; Doucette, P.A.; Nersissian, A.M.; Faull, K.F.; Eggers, D.K.; Tiwari, A.; Hayward, L.J.; et al. Destabilization of apoprotein is insufficient to explain Cu, Zn-superoxide dismutase-linked ALS pathogenesis. Proc. Natl. Acad. Sci. USA 2005, 102, 10516-10521. [CrossRef] [PubMed]

77. Bergemalm, D.; Jonsson, P.A.; Graffmo, K.S.; Andersen, P.M.; Brännström, T.; Rehnmark, A.; Marklund, S.L. Overloading of stable and exclusion of unstable human superoxide dismutase-1 variants in mitochondria of murine amyotrophic lateral sclerosis models. J. Neurosci. 2006, 26, 4147-4154. [CrossRef] [PubMed]

78. Elia, F.; Cantini, F.; Chiti, F.; Dobson, C.M.; Bemporad, F. Direct conversion of an enzyme from native-like to amyloid-like aggregates within inclusion bodies. Biophys. J. 2017, 112, 2540-2551. [CrossRef] [PubMed]

79. Das, A.; Plotkin, S.S. SOD1 exhibits allosteric frustration to facilitate metal binding affinity. Proc. Natl. Acad. Sci. USA 2013, 110, 3871-3876. [CrossRef] [PubMed]

80. Bruns, C.K.; Kopito, R.R. Impaired post-translational folding of familial ALS-linked Cu, Zn superoxide dismutase mutants. EMBO J. 2007, 26, 855-866. [CrossRef] [PubMed]

81. Teilum, K.; Smith, M.H.; Schulz, E.; Christensen, L.C.; Solomentsev, G.; Oliveberg, M.; Akke, M. Transient structural distortion of metal-free $\mathrm{Cu} / \mathrm{Zn}$ superoxide dismutase triggers aberrant oligomerization. Proc. Natl. Acad. Sci. USA 2009, 106, 18273-18278. [CrossRef] [PubMed]

82. Lynch, S.M.; Boswell, S.A.; Colón, W. Kinetic stability of $\mathrm{Cu} / \mathrm{Zn}$ superoxide dismutase is dependent on its metal ligands: Implications for ALS. Biochemistry 2004, 43, 16525-16531. [CrossRef] [PubMed]

83. Leinartaite, L.; Saraboji, K.; Nordlund, A.; Logan, D.T.; Oliveberg, M. Folding catalysis by transient coordination of $\mathrm{Zn}^{2+}$ to the $\mathrm{Cu}$ ligands of the ALS-associated enzyme $\mathrm{Cu} / \mathrm{Zn}$ superoxide dismutase 1. J. Am. Chem. Soc. 2010, 132, 13495-13504. [CrossRef] [PubMed] 
84. Kayatekin, C.; Zitzewitz, J.A.; Matthews, C.R. Zinc binding modulates the entire folding free energy surface of human Cu, Zn superoxide dismutase. J. Mol. Biol. 2008, 384, 540-555. [CrossRef] [PubMed]

85. Rakhit, R.; Crow, J.P.; Lepock, J.R.; Kondejewski, L.H.; Cashman, N.R.; Chakrabartty, A. Monomeric Cu, $\mathrm{Zn}$-superoxide dismutase is a common misfolding intermediate in the oxidation models of sporadic and familial amyotrophic lateral sclerosis. J. Biol. Chem. 2004, 279, 15499-15504. [CrossRef] [PubMed]

86. Shaw, B.F.; Durazo, A.; Nersissian, A.M.; Whitelegge, J.P.; Faull, K.F.; Valentine, J.S. Local unfolding in a destabilized, pathogenic variant of superoxide dismutase 1 observed with $H / D$ exchange and mass spectrometry. J. Biol. Chem. 2006, 281, 18167-18176. [CrossRef] [PubMed]

87. Durazo, A.; Shaw, B.F.; Chattopadhyay, M.; Faull, K.F.; Nersissian, A.M.; Valentine, J.S.; Whitelegge, J.P. Metal-free superoxide dismutase-1 and three different amyotrophic lateral sclerosis variants share a similar partially unfolded beta-barrel at physiological temperature. J. Biol. Chem. 2009, 284, 34382-34389. [CrossRef] [PubMed]

88. Ding, F.; Furukawa, Y.; Nukina, N.; Dokholyan, N.V. Local unfolding of Cu, Zn superoxide dismutase monomer determines the morphology of fibrillar aggregates. J. Mol. Biol. 2012, 421, 548-560. [CrossRef] [PubMed]

89. Furukawa, Y.; Kaneko, K.; Yamanaka, K.; O’Halloran, T.V.; Nukina, N. Complete loss of post-translational modifications triggers fibrillar aggregation of SOD1 in the familial form of amyotrophic lateral sclerosis. J. Biol. Chem. 2008, 283, 24167-24176. [CrossRef] [PubMed]

90. Bartnikas, T.B.; Gitlin, J.D. Mechanisms of biosynthesis of mammalian copper/zinc superoxide dismutase. J. Biol. Chem. 2003, 278, 33602-33608. [CrossRef] [PubMed]

91. Lyons, T.J.; Nersissian, A.; Huang, H.; Yeom, H.; Nishida, C.R.; Graden, J.A.; Gralla, E.B.; Valentine, J.S. The metal binding properties of the zinc site of yeast copper-zinc superoxide dismutase: Implications for amyotrophic lateral sclerosis. J. Biol. Inorg. Chem. 2000, 5, 189-203. [CrossRef] [PubMed]

92. Crow, J.P.; Sampson, J.B.; Zhuang, Y.; Thompson, J.A.; Beckman, J.S. Decreased zinc affinity of amyotrophic lateral sclerosis-associated superoxide dismutase mutants leads to enhanced catalysis of tyrosine nitration by peroxynitrite. J. Neurochem. 1997, 69, 1936-1944. [CrossRef] [PubMed]

93. Leal, S.S.; Cardoso, I.; Valentine, J.S.; Gomes, C.M. Calcium ions promote superoxide dismutase 1 (SOD1) aggregation into non-fibrillar amyloid: A link to toxic effects of calcium overload in amyotrophic lateral sclerosis (ALS)? J. Biol. Chem. 2013, 288, 25219-25228. [CrossRef] [PubMed]

94. Berridge, M.J.; Bootman, M.D.; Roderick, H.L. Calcium signalling: Dynamics, homeostasis and remodelling. Nat. Rev. Mol. Cell Biol. 2003, 4, 517-529. [CrossRef] [PubMed]

95. Winkler, D.D.; Schuermann, J.P.; Cao, X.; Holloway, S.P.; Borchelt, D.R.; Carroll, M.C.; Proescher, J.B.; Culotta, V.C.; Hart, P.J. Structural and biophysical properties of the pathogenic SOD1 variant H46R/H48Q. Biochemistry 2009, 48, 3436-3647. [CrossRef] [PubMed]

96. Leal, S.S.; Botelho, H.M.; Gomes, C.M. Metal ions as modulators of protein conformation and misfolding in neurodegeneration. Coord. Chem. Rev. 2012, 256, 2253-2270. [CrossRef]

97. Chiti, F.; Stefani, M.; Taddei, N.; Ramponi, G.; Dobson, C.M. Rationalization of the effects of mutations on peptide and protein aggregation rates. Nature 2003, 424, 805-808. [CrossRef] [PubMed]

98. DuBay, K.F.; Pawar, A.P.; Chiti, F.; Zurdo, J.; Dobson, C.M.; Vendruscolo, M. Prediction of the absolute aggregation rates of amyloidogenic polypeptide chains. J. Mol. Biol. 2004, 341, 1317-1326. [CrossRef] [PubMed]

99. Kurlander, H.M.; Patten, B.M. Metals in spinal cord tissue of patients dying of motor neuron disease. Ann. Neurol. 1979, 6, 21-24. [CrossRef] [PubMed]

100. Tokuda, E.; Furukawa, Y. Copper homeostasis as a therapeutic target in amyotrophic lateral sclerosis with SOD1 mutations. Int. J. Mol. Sci. 2016, 17. [CrossRef] [PubMed]

101. Tokuda, E.; Okawa, E.; Watanabe, S.; Ono, S.; Marklund, S.L. Dysregulation of intracellular copper homeostasis is common to transgenic mice expressing human mutant superoxide dismutase-1s regardless of their copper-binding abilities. Neurobiol. Dis. 2013, 54, 308-319. [CrossRef] [PubMed]

102. Bousser, M.G.; Malier, M. Penicillamine in amyotrophic lateral sclerosis. Lancet 1979, 1, 168. [CrossRef]

Sample Availability: Not available.

(C) 2017 by the authors. Licensee MDPI, Basel, Switzerland. This article is an open access article distributed under the terms and conditions of the Creative Commons Attribution (CC BY) license (http://creativecommons.org/licenses/by/4.0/). 